\section{Norwegian Minerals and Rocks of Possible Caledonian Origin}

IN a recent communication ${ }^{1}$ an outline is given of the sequence of metamorphic and structural events which affected the Lewisian rocks of the Glenelg inlier. In this outline a period of folding, about 740 million yoars old, and certainly older than 560 million years, is considered to form part of the Caledonian orogeny. Further can be mentioned the intrusion of the Ben Vuroch granite into Dalradian sediments between 700 and 500 million years ago $^{2}$.

These results are of importance for the discussion of the Norwegian part of the Caledonian chain. Age determinations $^{3}$ of minerals and rocks from three districts are referred to here. They may all be of Caledonian origin:

(1) Tho Rødsand mine is situated in the Molde-Kristiansund district, central Norway. A molybdenite from the mine gave the rhenium/osmium age $540( \pm 10 \%)$ million years.

(2) Two micas from pegmatites in the county of Sogn and Fjordane, Southern Norway, gave the potassium/ argon ages 582 and 590 million years.

(3) Potassium/argon determinations of micas in the carbonatite in the Fen area, $119 \mathrm{~km}$ south-west of Oslo, gave the ages 565, 590 and 603 million years.

According to my investigations in the Molde-Kristiansund district, we here have a Precambrian-post-Precambrian Caledonian stratigraphic sequence. The Precambrian part of this sequence is quite as important as the post-Precambrian part. A Precambrian basement is not found.

The two pegmatites in the county of Sogn and Fjordane are both situated in gneisses. These gneisses may belong to a Caledonian stratigraphic sequence, but are probably parts of the Precambrian basement. In both cases the rocks may have undergone an early Caledonian metamorphism.

According to Prof. J. Tuzo Wilson ${ }^{4}$, the graben in the South Norwegian sparagmite region can be considered to bolong to the Caledonian orogeny. The Fen area may have originated in connexion with these fuults.

The age determinations given hore indicate that the Precambrian-Cambrian part of the Norwegian Caledonian history is more important than is generally assumed.

T. HERNES

Geological Tnstitute,

University of Bergen, Norway.

${ }^{1}$ Miller, J. A., Barber, A. J., and Kempton, N. H., Nature, 197, 1095 (1963). ${ }^{2}$ Giletti, B. J., Moorbath, S., and Lambert, R. St. J., Quart. J. Geol. Soc., $117,233(1961)$.

${ }^{3}$ Neumann, H., Norsk Geol. T'idsskr., 40, 173 (1960).

4 Jacobs, J. A., Russell, R. D., and Wilson, J. Tuzo, Physics and Geology, 340 (MeGraw-Hill, New York, 1959).

\section{A Beacon Sandstone : its Petrology and Hydrocarbon Content}

After the ill-fated Scott expedition of 1910-13 a valuable suite of Antarctic rocks, collected by Sir Raymond Priestley, was donated to the University of Nottingham. In it was a specimen from the Beacon Sandstone series collected from Cape Royds. This we have investigated to see whether such a series might conceivably possess the properties of reservoir or souree rocks for oil.

The Beacon Sandstones extend throughout eastern Antarctica in the region of the Great Fault Scarp. The succession, consisting of nearly horizontal strata interleaved with dolerite sills, characterize the tabular mountains for more than a thousand miles ${ }^{1}$. In some places, such as north of the Mackay Glacier, the series is more than $3.500 \mathrm{ft}$. thick and has been subdivided into three main lithological divisions ${ }^{2}$. Unfortunately, we do not know to which of these subdivisions the Priestley specimen belongs.

In hand specimen it is a light-coloured, very coarsegrained, hard quartzite with numerous small pebbles. The sorting is rather poor and the grain size varies from $10 \mathrm{~mm}$ down to silt grade interstitial sediment. The majority of the pebbles are of unstrained quartz, the rest are of granite, gneiss, schist and quartzite. Very little cement has been introduced, and while a small proportion of the grains have a fringe of secondary quartz most of them are welded along common margins. Sporadically distributed throughout are small chalky patches and also small holes often lined with chalky material. On X-ray analysis this chalky substance has proved to be albite-rich alkali felspar. It is not known why the felspar is in this condition, and further investigation is required. Of interest and significanco to the present study are euhedra and granular aggregates of sphene. While no metamorphic significance is normally attached to this mineral, in somo instances elsewhere, it is clear that it has begun to crystallize at higher temperatures than associated epidote. The minimum temperature of formation of epidote is $160^{\circ} \mathrm{C}$, so that of sphene must be higher. If the recrystallization of the sphene and the quartz were at the same time, then the formation of the quartzite must have occurred above $160^{\circ} \mathrm{C}$.

In essence, therefore, this is a quartzite of low porosity of which the induration and association with dolerite intrusions would, at first sight, appear to rule out the possibility of the survival of hydrocarbons. Moreover, the rock was digested with hydrofluoric acid in order to

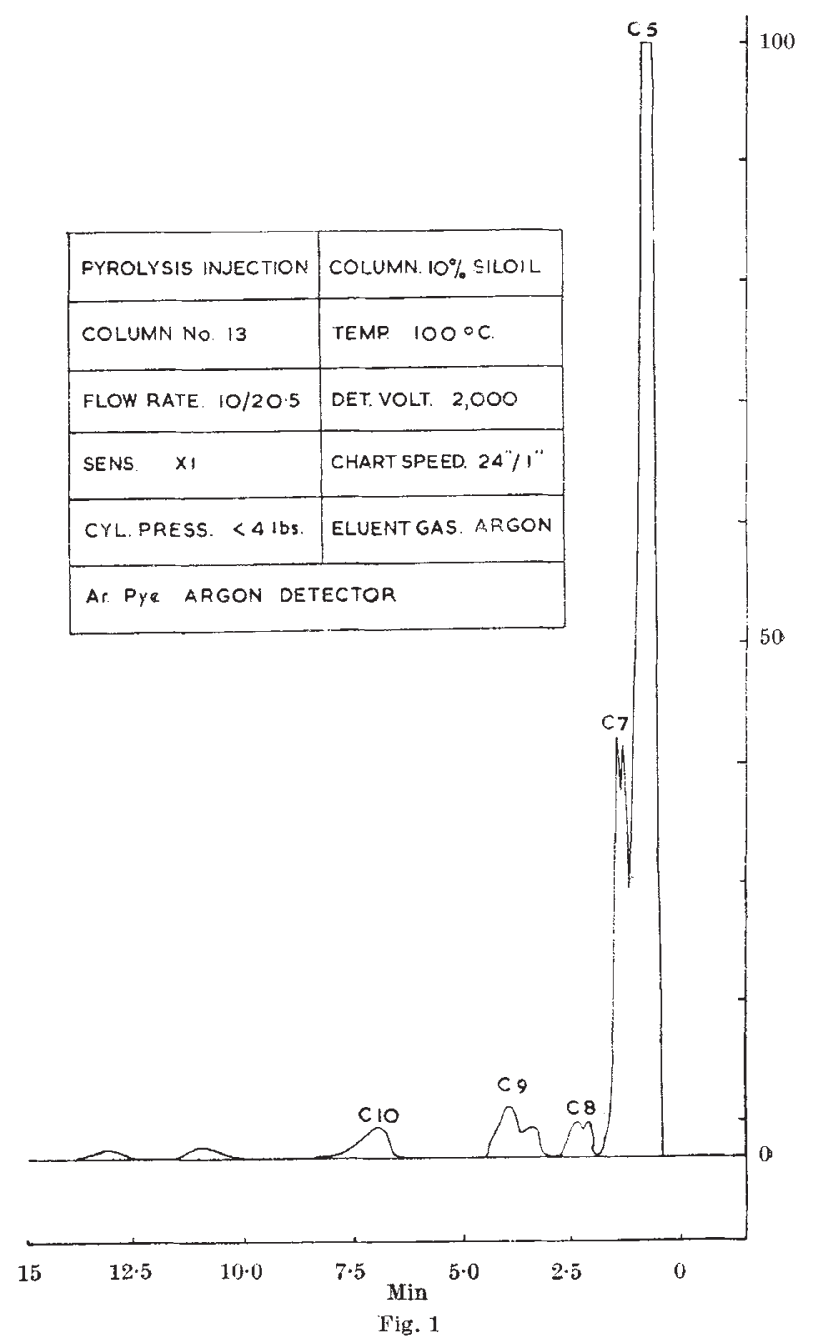

